\title{
The role of new antidepressants in clinical practice in Canada: a brief review of vortioxetine, levomilnacipran ER, and vilazodone
}

This article was published in the following Dove Press journal: Neuropsychiatric Disease and Treatment

\section{Roger S Mclntyre ${ }^{1,2}$}

'Department of Psychiatry, University of Toronto, ${ }^{2}$ Mood Disorders Psychopharmacology Unit, University Health Network, Toronto, ON, Canada
Correspondence: Roger S Mclntyre

Toronto Western Hospital, University Health Network, 399 Bathurst Street,

Toronto, ON M5T 2S8, Canada

Tel +4166035279

Fax +4I6 6035368

Email roger.mcintyre@uhn.ca
Abstract: Although many branded and generic antidepressants are approved for the treatment of major depressive disorder (MDD) in Canada, efficacy and tolerability differ among patients, and new treatment options are needed. Symptom types (eg, fatigue, energy/motivation, cognition, and functioning), medication type, treatment duration, and the need for maintenance therapy are factors that may influence treatment effectiveness. Three antidepressants, vortioxetine, levomilnacipran extended-release (ER), and vilazodone have recently become available in Canada. The aim of this review is to contextualize differences in their mechanistic and clinical profiles, thereby providing practitioners with knowledge to support treatment decisions. In trials versus placebo, each drug improved depressive symptoms in adult patients with MDD. The antidepressant effect of vortioxetine may be related to enhanced serotonergic activity via reuptake inhibition and agonism and/or antagonism of various serotonin receptors. Vortioxetine may also improve cognitive functioning in MDD, and has proven efficacious in relapse prevention. Nausea was the most commonly reported adverse event (AE); rates of sexual dysfunction were low and abrupt discontinuation was well tolerated. Levomilnacipran ER, a serotonin norepinephrine reuptake inhibitor, demonstrated greater improvement versus placebo in functional impairment as well as depressive symptoms; in post hoc analyses, improvement in symptoms of motivation and energy were observed. Nausea was the most commonly reported AE; gradual discontinuation is recommended to avoid discontinuation syndrome. Vilazodone is a serotonin reuptake inhibitor and partial serotonergic 5- $\mathrm{HT}_{1 \mathrm{~A}}$ receptor agonist. In addition to improvement in depressive symptoms, evidence suggests that vilazodone may be particularly well suited for depressed patients with high anxiety levels. Diarrhea, nausea, and headache were the most common AEs; low rates of sexual dysfunction were reported. The 2016 Canadian Network for Mood and Anxiety Treatments guidelines for MDD includes vortioxetine as a first-line treatment; levomilnacipran ER and vilazodone are considered as second-line treatments due to lack of relapse prevention data at the time of approval.

Keywords: serotonin reuptake inhibitor, norepinephrine reuptake inhibitor, depression, major depressive disorder

\section{Plain language summary}

Major depressive disorder (MDD) and major depressive episodes are associated with diverse symptoms that cause considerable dysfunction and impairment for patients. Although numerous antidepressants are available in Canada, each patient responds differently to these agents and no single medication has proven itself suitable for everyone. Three new antidepressants - vortioxetine, levomilnacipran extended-release (ER), and vilazodone - have recently become available in Canada. Since each drug has different safety and efficacy characteristics, it is important for clinicians to become familiar with them so they can be used successfully in the clinic. In clinical 
trials, patients treated with any of the 3 new antidepressants had greater improvement in depressive symptoms than patients treated with placebo; vortioxetine has also demonstrated efficacy in relapse prevention. All 3 antidepressants are generally safe and well tolerated; in clinical trials, nausea was the most common side effect for vortioxetine and levomilnacipran ER, while diarrhea, nausea, and headache were common with vilazodone. The Canadian Network for Mood and Anxiety Treatments guidelines recommend vortioxetine as a first-line treatment for MDD, and levomilnacipran ER and vilazodone are considered as second-line options.

\section{Introduction}

Major depressive disorder (MDD) and major depressive episode (MDE) are the leading causes of disability in Canada. The majority of patients with MDD experience recurrent or chronic depression (persistence of depressive symptoms for $\geq 2$ years), while patients with MDE have an average episode duration of 6 months. ${ }^{1}$ The prevalence of MDD or MDE does not appear to be decreasing, despite the availability of psychotherapy and pharmacologic treatments. ${ }^{2}$ Canadian Community Health Study-Mental Health surveys indicate that lifetime and 12-month prevalence rates of MDD and MDE in $2012^{3}$ were similar to those in $2002 .{ }^{4}$ Specifically, lifetime MDD prevalence was $10.8 \%$ in 2002 and $9.9 \%$ in 2012, while 12-month prevalence was $4.0 \%$ in 2002 and $3.9 \%$ in 2012. Similarly, lifetime MDE prevalence was $12.2 \%$ in 2002 and $11.3 \%$ in 2012, while 12-month prevalence was $4.8 \%$ in 2002 and $4.7 \%$ in 2012. Since major depression has been associated with reduced quality of life and decreased life expectancy, ${ }^{5}$ it is a public health concern in Canada.

Although many factors contribute to the continued prevalence of MDD and MDE, the need for better prevention strategies and better quality of treatment is evident. ${ }^{2}$ Many antidepressants are approved for the treatment of MDD in Canada, with generic equivalents available for several branded drugs. The most commonly prescribed antidepressant is the serotonin and norepinephrine reuptake inhibitor (SNRI) venlafaxine, followed by the selective serotonin reuptake inhibitor (SSRI) citalopram (Allergan, data on file, February 2017). Of interest, antidepressants in the SNRI class are prescribed at a higher rate in Canada (30\%) than in the USA ( 19\%) (Allergan, data on file, February 2017). Since symptoms such as energy and concentration difficulties are directly associated with the noradrenergic system, ${ }^{6}$ SNRIs, which increase levels of both serotonin and norepinephrine, may offer advantages for improving depressive symptoms as well as associated functional impairment. However, no single medication has proven itself suitable for all patients, and current prevalence rates for major depression suggest that some sectors of the population are not receiving adequate treatment despite available treatment options.

MDD is heterogeneous in nature comprising disturbances across distinct psychopathological symptoms/domains. Neurochemical (eg, dopaminergic, serotonergic, and noradrenergic) differences in the etiology of symptoms account for some of the heterogeneity in MDD. ${ }^{7}$ However, symptombased diagnostics greatly contribute to heterogeneity in patient identification since multiple combinations of symptoms from the polythetic list of the Diagnostic and Statistical Manual of Mental Disorders, Fifth Edition (DSM-5) can qualify a patient for an MDE diagnosis. ${ }^{1,8}$ It is recognized that the full spectrum of clinical presentations for an MDE is not completely covered by existing symptom criteria, but it may include clinical dimensions (eg, reward abnormalities) with overlapping yet discreet substrates that affect the prognosis and treatment of MDD. ${ }^{9}$ Although episode and course specifiers for an MDE have been retained in the DSM-5, ${ }^{1}$ some clinical dimensions (eg, cognitive dysfunction, sleep disturbances, and somatic symptoms) may not be adequately represented. ${ }^{9}$ Domain- and dimension-based clinical research approaches in MDD reflect the heterogeneous features of an MDE and attempt to better characterize the domains (eg, fatigue, psychomotor retardation, and lack of motivation) that are relevant to patient-reported outcomes such as quality of life and functional impairment.

Differences in symptoms (eg, fatigue, energy/motivation, and cognitive or functional difficulties), medication type, treatment duration, need for maintenance therapy, and concomitant behavioral therapies are among the factors that influence treatment effectiveness. Currently, many adults with MDD fail to respond adequately to pharmacotherapy and improved therapeutic strategies could benefit patients, providers, and society. In Canada, 3 antidepressant agents have recently become available. This recent and contemporaneous introduction of several new antidepressants provides the impetus to contextualize the differences in their respective mechanistic and clinical profiles. The overarching aim of this review is to provide practitioners with knowledge to support the decision to select any of the new-entry treatments.

\section{Overview of new antidepressants in Canada}

Between publication of the 2009 and 2016 Canadian Network for Mood and Anxiety Treatments (CANMAT) guidelines, vortioxetine, levomilnacipran extended-release (ER), and vilazodone were approved in Canada for the treatment of MDD (Table 1). Vortioxetine has level 1 evidence and is a 
Table I New antidepressants in the Canadian market

\begin{tabular}{|c|c|c|c|}
\hline Characteristic & Vortioxetine (Trintellix) & Levomilnacipran ER (Fetzima ${ }^{\circledR}$ ) & Vilazodone (Viibryd $^{\circledR}$ ) \\
\hline Health Canada approval & October 2014 & May 2015 & July 2015 \\
\hline Indication & Major depressive disorder & Major depressive disorder & Major depressive disorder \\
\hline Mechanism of action ${ }^{a}$ & $\begin{array}{l}\text { Selective serotonin reuptake } \\
\text { inhibitor, } \\
5-\mathrm{HT}_{3} \text { antagonist, } \\
5-\mathrm{HT}_{\mid \mathrm{A}} \text { agonist }\end{array}$ & $\begin{array}{l}\text { Serotonin and norepinephrine reuptake } \\
\text { inhibitor }\end{array}$ & $\begin{array}{l}\text { Selective serotonin reuptake } \\
\text { inhibitor and } 5-\mathrm{HT}_{\text {IA }} \text { partial } \\
\text { agonist }\end{array}$ \\
\hline Dosing recommendation & $\begin{array}{l}\text { Once-daily with or without food; } \\
\text { initiate at } 10 \mathrm{mg} / \text { day and increase } \\
\text { to } 20 \mathrm{mg} / \text { day as tolerated; dose can } \\
\text { be reduced to } 5 \mathrm{mg} / \text { day in patients } \\
\text { who do not tolerate higher doses }\end{array}$ & $\begin{array}{l}\text { Once-daily with or without food; } \\
\text { initiate at } 20 \mathrm{mg} / \text { day for } 2 \text { days and } \\
\text { increase to } 40 \mathrm{mg} / \text { day; increase by } \\
40 \mathrm{mg} \text { increments to } 120 \mathrm{mg} / \text { day at } \\
\text { 2-day intervals, as needed and tolerated }\end{array}$ & $\begin{array}{l}\text { Once-daily with food; initiate } \\
\text { at } 10 \mathrm{mg} / \text { day for } 7 \text { days; } \\
\text { increase to } 20 \mathrm{mg} / \text { day then } 40 \\
\mathrm{mg} / \text { day at } 7 \text {-day intervals, as } \\
\text { needed and tolerated }\end{array}$ \\
\hline $\begin{array}{l}\text { Primary efficacy measures } \\
\text { in clinical trials }\end{array}$ & MADRS or HAM-D & MADRS & MADRS \\
\hline $\begin{array}{l}\text { Additional measures of } \\
\text { interest }\end{array}$ & SDS, DSST & SDS, MEI & HAM-A, CSFQ, ASEX \\
\hline 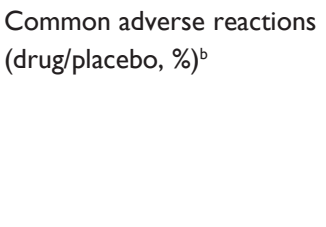 & $\begin{array}{l}\text { Nausea }(26 / 9) \text {, diarrhea }(8 / 6) \text {, } \\
\text { dry mouth }(7 / 6) \text {, dizziness }(7 / 6) \text {, } \\
\text { constipation }(5 / 3) \text {, vomiting }(5 / 1)\end{array}$ & $\begin{array}{l}\text { Nausea }(17 / 6) \text {, constipation }(9 / 3) \text {, } \\
\text { hyperhidrosis }(9 / 2) \text {, tachycardia }(6 / 2) \text {, } \\
\text { erectile dysfunction }(6 / 1 \text { [men only]), } \\
\text { heart rate increased }(6 / 1) \text {, vomiting } \\
(5 / 1) \text {, palpitations }(5 / 1) \text {, ejaculation } \\
\text { disorder }(5 /<I \text { [men only]) }\end{array}$ & $\begin{array}{l}\text { Diarrhea }(28 / / 0) \text {, nausea } \\
(24 / 7) \text {, headache }(14 / \mid 4) \text {, dry } \\
\text { mouth }(7 / 5) \text {, insomnia }(6 / 2) \text {, } \\
\text { vomiting }(5 / 2) \text {, somnolence } \\
(5 / 2) \text {, abdominal pain }(5 / 3)\end{array}$ \\
\hline
\end{tabular}

Notes: aProposed mechanism of action based on current knowledge; mechanisms are not fully understood for any of these 3 medications. ${ }^{b}$ Reported in $\geq 5 \%$ of actively treated patients in any dose group (vortioxetine, vilazodone) or all dose groups combined (levomilnacipran ER), as analyzed and described in the relevant US prescribing information; percent values presented in the table are based on all dose groups combined.

Abbreviations: ASEX, Arizona Sexual Experiences Scale; CSFQ, Changes in Sexual Functioning Questionnaire; DSST, digit symbol substitution test; ER, extended-release; HAM-A, Hamilton Rating Scale for Anxiety; HAM-D, Hamilton Rating Scale for Depression; MADRS, Montgomery-Åsberg Depression Rating Scale; MEI, Motivation and Energy Inventory; SDS, Sheehan Disability Scale.

first-line treatment for MDD; although levomilnacipran ER and vilazodone also have level 1 evidence, lack of clinical experience in prescribing them and limited long-term efficacy data currently relegate them to second-line treatments. ${ }^{10}$

\section{Vortioxetine}

Mechanisms underlying the antidepressant effects of vortioxetine are not fully understood, but enhancement of serotonergic activity via reuptake inhibition is believed to be a contributing factor; other potential mechanisms include agonism and/or antagonism of various serotonin receptors $\left(\mathrm{eg}, 5-\mathrm{HT}_{1 \mathrm{~A}}, 5-\mathrm{HT}_{1 \mathrm{~B}}, 5-\mathrm{HT}_{3}, 5-\mathrm{HT}_{1 \mathrm{D}}\right.$, and 5- $\left.\mathrm{HT}_{7}\right){ }^{11,12}$ Vortioxetine is taken once daily with or with out food; ${ }^{11}$ the recommended starting dose is $10 \mathrm{mg}$ /day, which can be increased to $20 \mathrm{mg}$ /day as needed and tolerated. Lowering the dose to $5 \mathrm{mg}$ /day may be considered in patients with tolerability issues. Importantly, vortioxetine is associated with a low level of discontinuation symptoms, which may be partly related to its relatively long elimination half-life, and abrupt discontinuation is well tolerated. ${ }^{13,14}$

In Canada, approval of vortioxetine for the acute treatment of MDD was based on a review of 11 short-term ( 6 or 8 weeks) Phase III studies, which included 6 positive studies of vortioxetine 5-20 mg/day in adults, ${ }^{15-17}$ vortioxetine $20 \mathrm{mg}$ /day in adults, ${ }^{18,19}$ and vortioxetine $5 \mathrm{mg}$ /day in older adults ( $\geq 65$ years). ${ }^{20}$ In non-US trials, efficacy was shown across a wide dose range, with lower doses $(5,10$, and $15 \mathrm{mg} /$ day $)$ and the highest dose (20 mg/day) reaching statistical significance versus placebo. In US trials, only the $20 \mathrm{mg}$ /day dose was significantly different than placebo, which led the US Food and Drug Administration to recommend a starting dose of $10 \mathrm{mg}$ /day, with an increase to $20 \mathrm{mg} /$ day as tolerated. ${ }^{11}$

In a meta-analysis of vortioxetine studies, significantly greater decreases in Montgomery-Åsberg Depression Rating Scale (MADRS) total score were shown for vortioxetine $\left(5,10\right.$, and $20 \mathrm{mg} /$ day) versus placebo. ${ }^{21}$ Treatment effects appeared to be dose-related, which is consistent with the dose-related pharmacokinetics of vortioxetine. ${ }^{11}$ Placebocontrolled studies also suggest that treatment with vortioxetine can improve cognitive functioning in patients with MDD, independent of the drug's effects on symptoms of depression. ${ }^{22-24}$ It is hypothesized that the procognitive effects of vortioxetine involve a combination of monoaminergic and glutamatergic effects. ${ }^{23}$ Vortioxetine has also been shown to prevent MDD relapse and is well tolerated as maintenance therapy. ${ }^{25}$ Nausea was the only adverse event (AE) reported in $>10 \%$ of all vortioxetine-treated patients during placebocontrolled trials (Table 1). ${ }^{11}$ Given that sexual dysfunction is 
a known side effect of antidepressant treatment, it is noteworthy that vortioxetine has demonstrated placebo-level sexual dysfunction at initiation doses of $10 \mathrm{mg} /$ day. ${ }^{13}$ Although rates of sexual dysfunction are higher at doses of 15-20 mg/day compared with $10 \mathrm{mg} /$ day (albeit lower than SSRI treatment), switching to vortioxetine has been shown to be beneficial for patients experiencing sexual dysfunction during antidepressant therapy with SSRIs. ${ }^{27}$ Sexual dysfunction was reported in $<2 \%$ of placebo- and vortioxetine-treated patients in placebo-controlled trials. ${ }^{13}$

\section{Levomilnacipran ER}

Levomilnacipran ER, the more active enantiomer of the racemic drug milnacipran, is an SNRI with preferential inhibition of norepinephrine reuptake in vitro. ${ }^{28,29}$ Levomilnacipran exhibits higher affinity for norepinephrine and serotonin transporters and more potently inhibits norepinephrine and serotonin reuptake than milnacipran. ${ }^{29}$ The recommended dose is 40-120 mg once daily, with or without food; levomilnacipran ER is initiated at $20 \mathrm{mg} /$ day for 2 days and then increased to $40 \mathrm{mg} /$ day. Based on tolerability and efficacy, the dose can be increased in $40 \mathrm{mg} /$ day increments every 2 or more days until the highest recommended dose (120 mg/day) is reached. ${ }^{28}$ Since symptoms (eg, nausea, sweating, dysphoric mood, irritability, agitation, and dizziness) have been reported when serotonergic drugs are discontinued, gradual dose reduction, instead of abrupt discontinuation, is recommended for levomilnacipran ER whenever possible. Patients should be monitored and a more gradual dose reduction can be considered if symptoms are intolerable. $^{28}$

Four short-term ( 8 or 10 weeks) placebo-controlled trials of levomilnacipran ER were included in the Health Canada review, including 3 positive studies ( 2 fixed $\operatorname{dose}^{30,31}$ and 1 flexible dose $^{32}$ ). In these studies, changes from baseline in MADRS total score (primary endpoint) and Sheehan Disability Scale (SDS; secondary endpoint) were significantly different in favor of levomilnacipran ER versus placebo, indicating greater improvement in depressive symptoms and functional impairment. Among the SDS subscales, significant improvement was also found on the work subscale in all 3 studies, and on the social life and family life subscales in 2 studies. At the time of the Health Canada review, a levomilnacipran ER relapse prevention study had not been completed (NCT02288325); however, subsequently reported results showed that continued treatment in patients who had responded to levomilnacipran ER (40-120 mg/day) significantly reduced the risk of relapse relative to placebo over 26 weeks of double-blind treatment. ${ }^{33}$
Post hoc analyses of clinical study data have indicated that levomilnacipran ER can improve motivation and energy, ${ }^{34}$ which is consistent with its noradrenergic effects. ${ }^{35}$ Larger treatment effects on functional impairment and mental functional health were observed in patients with low versus high baseline motivation and energy. ${ }^{34}$ In addition, a metaanalysis of 5 randomized placebo-controlled studies showed that levomilnacipran ER improved depression across a range of symptoms and symptom domains, including anhedonia and retardation. ${ }^{36}$

In placebo-controlled trials, nausea was the only $\mathrm{AE}$ reported in $>10 \%$ of all levomilnacipran ER-treated patients (Table 1). ${ }^{28}$ No unexpected or inconsistent safety issues were found during a 48-week open-label extension study in which patients received levomilnacipran ER (40, 80, or $120 \mathrm{mg} /$ day $)^{37}$ or during the relapse prevention trial. ${ }^{33}$

\section{Vilazodone}

Vilazodone is a serotonin reuptake inhibitor and partial serotonergic 5- $\mathrm{HT}_{1 \mathrm{~A}}$ receptor agonist. ${ }^{38}$ The recommended target dose is $20-40 \mathrm{mg} /$ day taken once daily with food. The initial 10 -mg/day dose is taken for 7 days, followed by increases to $20 \mathrm{mg} /$ day then to $40 \mathrm{mg} /$ day, with intervals of 7 days or more in between; this slower dose titration is recommended to avoid acute gastrointestinal side effects that may develop initially. ${ }^{38,39}$ Additionally, to avoid adverse reactions associated with serotonin discontinuation syndrome, gradual dosage reduction, rather than abrupt cessation, is recommended when treatment with vilazodone is discontinued. ${ }^{38}$

In the 4 short-term ( 8 or 10 weeks) Phase III trials that were reviewed for Canadian approval, significantly greater improvements in depression symptoms were seen with vilazodone (20-40 mg/day) versus placebo. ${ }^{40-43}$ In a post hoc pooled analysis of data from 2 clinical trials, statistically significant differences in favor of vilazodone versus placebo were seen in changes from baseline on rating scales measuring depression, global illness severity, and anxiety; significant improvement was also seen for vilazodone versus placebo on each individual item of the MADRS, suggesting efficacy across a spectrum of depressive symptoms. ${ }^{44}$ Additional post hoc analyses of MDD clinical trial data, ${ }^{45}$ along with results from clinical studies in patients with generalized anxiety disorder, ${ }^{46-48}$ suggest that vilazodone may be particularly well suited for patients suffering from depression and having high levels of anxiety.

In placebo-controlled trials, AEs reported in $>10 \%$ of all vilazodone-treated patients included diarrhea, nausea, and headache (Table 1). ${ }^{38}$ No unexpected safety concerns were found in a 12-month open-label study of vilazodone 
$40 \mathrm{mg}$ /day in patients with MDD. ${ }^{49}$ Weight gain in the longterm MDD study was small (mean increase $+1.7 \mathrm{~kg}$ ), ${ }^{49}$ in contrast to mean weight gains seen in long-term studies of other SSRI drugs (up to $\sim 10 \mathrm{~kg}$ ). ${ }^{50}$ Additionally, vilazodone had no significant placebo-subtracted effect on sexual functioning in patients with $\mathrm{MDD}^{51}$ or in healthy adult volunteers, ${ }^{52}$ which is an important factor to consider when treating patients with sexual dysfunction associated with antidepressant treatment or with depressive disorder itself.

\section{Treatment considerations, algorithms, and evidence-based guidelines}

Although existing treatment guidelines and algorithms for depression may differ in terms of specific steps, they generally encourage an individualized approach that considers specific factors that may contribute to the treatment outcome (eg, concomitant medications, tolerability, and prominent symptoms). Concomitant medications and potential drug interactions should be considered when selecting treatments. Based on in vitro studies, levomilnacipran ER is predicted to have low potential for pharmacokinetic drug interactions. ${ }^{28}$ Vortioxetine dose should be reduced by half when co-administered with a strong CYP2D6 inhibitor (eg, bupropion, fluoxetine, paroxetine, and quinidine), and the dose may need to be increased when co-administered with a strong CYP inducer (eg, rigamipin, carbamazepine, and phenytoin). ${ }^{26}$ Vilazodone dose should not exceed $20 \mathrm{mg} /$ day when co-administered with strong CYP3A4 inhibitors, and the dose may need to be increased when co-administered with CYP3A4 inducers. ${ }^{38}$ Additionally, for all the 3 drugs, co-administration with other serotonergic drugs should be closely monitored due to increased risk of serotonin syndrome.

The 2016 CANMAT algorithm ${ }^{10}$ includes vortioxetine, several SNRIs (eg, venlafaxine), and several SSRIs as firstline treatments based on a systematic literature review of antidepressants that evaluated quality of evidence and clinical expert consensus; agomelatine, bupropion, and mirtazapine are additional first-line recommendations. Levomilnacipran ER and vilazodone are included as second-line treatments due, in part, to the lack of relapse prevention data; however, as noted previously, top-line results from a recently completed study indicate that levomilnacipran ER has significant effects on relapse prevention relative to placebo. ${ }^{33}$ The Florida Best Practice Psychotherapeutic Medication Guidelines for Adults (2015) begins with a recommendation to assess the history of hypomania/mania, psychiatric and medical comorbidities, DSM-5 specifiers (eg, psychosis, mixed features, and suicidality), and the presence of cognitive dysfunction. ${ }^{53}$ For initial treatment of MDD with no specifiers or MDD with mixed features, this guideline includes SSRIs (eg, vilazodone), SNRIs (eg, levomilnacipran ER), and vortioxetine (in patients with cognitive complaints). For MDD with psychosis, the first-line recommendation is an SSRI or SNRI in conjunction with a second-generation antipsychotic medication; the guideline does caution, however, that risks for extrapyramidal symptoms, weight gain, and metabolic concerns should be considered before initiating adjunctive antipsychotic treatment.

\section{Conclusion}

Many clinical features and medication characteristics influence the choice of antidepressant treatment. Since the relative differences in efficacy between available medications are small, selecting an antidepressant should involve assessing individualized patient needs, symptoms, and preferences.

\section{Acknowledgments}

Writing and editorial assistance was provided by Mildred Bahn, MA, at Prescott Medical Communications Group (Chicago, IL, USA), with support from Allergan (Jersey City, NJ, USA) in accordance with Good Publication Practice (GPP3) guidelines (http://www.ismpp.org/gpp3).

\section{Author contribution}

Dr. McIntyre provided the initial outline and maintained full control over the direction and development of the manuscript. The author contributed toward data analysis, drafting, and revising the paper and agrees to be accountable for all aspects of the work.

\section{Disclosure}

Dr. McIntyre has received research grant support from Lundbeck, AstraZeneca, Pfizer, Shire, Otsuka, Bristol-Myers Squibb, National Institute of Mental Health, Stanley Medical Research Institute, Canadian Institutes for Health Research, and The Brain and Behavior Research Foundation. He has also received speaker/consultant fees from Lundbeck, Pfizer, AstraZeneca, Eli Lilly, Janssen Ortho, Sunovion, Takeda, Forest, Otsuka, Bristol-Myers Squibb, and Shire. The author reports no other conflicts of interest in this work.

\section{References}

1. American Psychiatric Association. Diagnostic and Statistical Manual of Mental Disorders. 5th ed. Washington, DC: American Psychiatric Association; 2013.

2. Patten SB, Williams JV, Lavorato DH, et al. Why is major depression prevalence not changing? J Affect Disord. 2016;190:93-97. 
3. Patten SB, Williams JV, Lavorato DH, et al. Descriptive epidemiology of major depressive disorder in Canada in 2012. Can J Psychiatry. 2015; 60(1):23-30.

4. Patten SB, Wang JL, Williams JV, et al. Descriptive epidemiology of major depression in Canada. Can J Psychiatry. 2006;51(2):84-90.

5. Steensma C, Loukine L, Orpana H, et al. Describing the population health burden of depression: health-adjusted life expectancy by depression status in Canada. Health Promot Chronic Dis Prev Can. 2016;36(10): 205-213.

6. Blier P, Briley $\mathrm{M}$. The noradrenergic symptom cluster: clinical expression and neuropharmacology. Neuropsychiatr Dis Treat. 2011; 7(Suppl 1):15-20.

7. Nutt DJ. Relationship of neurotransmitters to the symptoms of major depressive disorder. J Clin Psychiatry. 2008;69(Suppl E1):4-7.

8. Fried EI, Nesse RM. Depression sum-scores don't add up: why analyzing specific depression symptoms is essential. BMC Med. 2015; 13:72.

9. Lam RW, McIntosh D, Wang J, et al. Canadian Network for Mood and Anxiety Treatments (CANMAT) 2016 Clinical guidelines for the management of adults with major depressive disorder: section 1. Disease burden and principles of care. Can J Psychiatry. 2016;61(9): 510-523.

10. Kennedy SH, Lam RW, McIntyre RS, et al. Canadian Network for Mood and Anxiety Treatments (CANMAT) 2016 Clinical guidelines for the management of adults with major depressive disorder: section 3 . Pharmacological treatments. Can J Psychiatry. 2016;61(9):540-560.

11. Trintellix (vortioxetine). US prescribing information. Deerfield (IL): Takeda Pharmaceuticals America, Inc; 2016.

12. Katona CL, Katona CP. New generation multi-modal antidepressants: focus on vortioxetine for major depressive disorder. Neuropsychiatr Dis Treat. 2014;10:349-354.

13. Baldwin DS, Chrones L, Florea I, et al. The safety and tolerability of vortioxetine: analysis of data from randomized placebo-controlled trials and open-label extension studies. J Psychopharmacol. 2016; 30(3):242-252.

14. Sanchez C, Asin KE, Artigas F. Vortioxetine, a novel antidepressant with multimodal activity: review of preclinical and clinical data. Pharmacol Ther. 2015;145:43-57.

15. Alvarez E, Perez V, Dragheim M, et al. A double-blind, randomized, placebo-controlled, active reference study of Lu AA21004 in patients with major depressive disorder. Int J Neuropsychopharmacol. 2012; 15(5):589-600.

16. Henigsberg N, Mahableshwarkar AR, Jacobsen P, et al. A randomized, double-blind, placebo-controlled 8-week trial of the efficacy and tolerability of multiple doses of Lu AA21,004 in adults with major depressive disorder. J Clin Psychiatry. 2012;73(7):953-959.

17. Boulenger JP, Loft H, Olsen CK. Efficacy and safety of vortioxetine (Lu AA21004), 15 and $20 \mathrm{mg}$ /day: a randomized, double-blind, placebocontrolled, duloxetine-referenced study in the acute treatment of adult patients with major depressive disorder. Int Clin Psychopharmacol. 2014;29(3):138-149.

18. Mahableshwarkar AR, Jacobsen PL, Chen Y, et al. A randomized, double-blind, duloxetine-referenced study comparing efficacy and tolerability of 2 fixed doses of vortioxetine in the acute treatment of adults with MDD. Psychopharmacology (Berl). 2015;232(12): 2061-2070.

19. Jacobsen PL, Mahableshwarkar AR, Serenko M, et al. A randomized, double-blind, placebo-controlled study of the efficacy and safety of vortioxetine $10 \mathrm{mg}$ and $20 \mathrm{mg}$ in adults with major depressive disorder. J Clin Psychiatry. 2015;76(5):575-582.

20. Katona C, Hansen T, Olsen CK. A randomized, double-blind, placebocontrolled, duloxetine-referenced, fixed-dose study comparing the efficacy and safety of Lu AA21,004 in elderly patients with major depressive disorder. Int Clin Psychopharmacol. 2012;27(4):215-223.

21. Thase ME, Mahableshwarkar AR, Dragheim M, et al. A meta-analysis of randomized, placebo-controlled trials of vortioxetine for the treatment of major depressive disorder in adults. Eur Neuropsychopharmacol. 2016;26(6):979-993.
22. McIntyre RS, Florea I, Tonnoir B, Loft H, Lam RW, Christensen MC. Efficacy of vortioxetine on cognitive functioning in working patients with major depressive disorder. J Clin Psychiatry. 2017;78(1): $115-121$.

23. McIntyre RS, Harrison J, Loft H, Jacobson W, Olsen CK. The effects of vortioxetine on cognitive function in patients with major depressive disorder: a meta-analysis of three randomized controlled trials. Int $J$ Neuropsychopharmacol. Epub 2016 Aug 24.

24. Rosenblat JD, Kakar R, McIntyre RS. The cognitive effects of antidepressants in major depressive disorder: a systematic review and metaanalysis of randomized clinical trials. Int J Neuropsychopharmacol. 2015;19(2):1-13.

25. Boulenger JP, Loft H, Florea I. A randomized clinical study of $\mathrm{Lu}$ AA21,004 in the prevention of relapse in patients with major depressive disorder. J Psychopharmacol. 2012;26(11):1408-1416.

26. Trintellix (vortioxetine). Product monograph. St-Laurent, Quebec, Canada: Lundbeck Canada Inc; 2016.

27. Jacobsen PL, Mahableshwarkar AR, Chen Y, et al. Effect of vortioxetine versus. escitalopram on sexual functioning in adults with well-treated major depressive disorder experiencing SSRI-Induced sexual dysfunction. $J$ Sex Med. 2015;12(10):2036-2048.

28. Fetzima (levomilnacipran extended release). US prescribing information. Irvine, CA: Allergan USA, Inc; 2017.

29. Auclair AL, Martel JC, Assie MB, et al. Levomilnacipran (F2695), a norepinephrine-preferring SNRI: profile in vitro and in models of depression and anxiety. Neuropharmacology. 2013;70:338-347.

30. Asnis GM, Bose A, Gommoll CP, et al. Efficacy and safety of levomilnacipran sustained release $40 \mathrm{mg}, 80 \mathrm{mg}$, or $120 \mathrm{mg}$ in major depressive disorder: a phase 3, randomized, double-blind, placebo-controlled study. J Clin Psychiatry. 2013;74(3):242-248.

31. Bakish D, Bose A, Gommoll C, et al. Levomilnacipran ER $40 \mathrm{mg}$ and $80 \mathrm{mg}$ in patients with major depressive disorder: a phase III, randomized, double-blind, fixed-dose, placebo-controlled study. J Psychiatry Neurosci. 2014;39(1):40-49.

32. Sambunaris A, Bose A, Gommoll CP, et al. A phase III, doubleblind, placebo-controlled, flexible-dose study of levomilnacipran extended-release in patients with major depressive disorder. J Clin Psychopharmacol. 2014;34(1):47-56.

33. Durgam S, Chen C, Migliore R, et al. Relapse prevention with levomilnacipran ER in adults with major depressive disorder: a multicenter, randomized, double-blind, placebo-controlled study [abstract]. American Psychiatric Association Annual Meeting; May 20-24; 2017; San Diego, CA.

34. Thase ME, Gommoll C, Chen C, et al. Effects of levomilnacipran extended-release on motivation/energy and functioning in adults with major depressive disorder. Int Clin Psychopharmacol. 2016;31(6): 332-340.

35. Bruno A, Morabito P, Spina E, et al. The role of levomilnacipran in the management of major depressive disorder: a comprehensive review. Curr Neuropharmacol. 2016;14(2):191-199.

36. McIntyre RS, Gommoll C, Chen C, et al. The efficacy of levomilnacipran ER across symptoms of major depressive disorder: a post hoc analysis of 5 randomized, double-blind, placebo-controlled trials. CNS Spectr. 2016;21(5):385-392.

37. Mago R, Forero G, Greenberg WM, et al. Safety and tolerability of levomilnacipran ER in major depressive disorder: results from an open-label, 48-week extension study. Clin Drug Investig. 2013;33(10): 761-771.

38. Viibryd (vilazodone). US prescribing information. Irvine, CA: Allergan USA, Inc; 2017.

39. Singh M, Schwartz TL. Clinical utility of vilazodone for the treatment of adults with major depressive disorder and theoretical implications for future clinical use. Neuropsychiatr Dis Treat. 2012;8: 123-130.

40. Rickels K, Athanasiou M, Robinson DS, et al. Evidence for efficacy and tolerability of vilazodone in the treatment of major depressive disorder: a randomized, double-blind, placebo-controlled trial. JClin Psychiatry. 2009;70(3):326-333. 
41. Khan A, Cutler AJ, Kajdasz DK, et al. A randomized, double-blind, placebo-controlled, 8-week study of vilazodone, a serotonergic agent for the treatment of major depressive disorder. J Clin Psychiatry. 2011; 72(4):441-447.

42. Mathews M, Gommoll C, Chen D, et al. Efficacy and safety of vilazodone 20 and $40 \mathrm{mg}$ in major depressive disorder: a randomized, double-blind, placebo-controlled trial. Int Clin Psychopharmacol. 2015;30(2):67-74

43. Croft HA, Pomara N, Gommoll C, et al. Efficacy and safety of vilazodone in major depressive disorder: a randomized, double-blind, placebocontrolled trial. J Clin Psychiatry. 2014;75(11):e1291-e1298.

44. Khan A, Sambunaris A, Edwards J, et al. Vilazodone in the treatment of major depressive disorder: efficacy across symptoms and severity of depression. Int Clin Psychopharmacol. 2014;29(2):86-92.

45. Thase ME, Chen D, Edwards J, et al. Efficacy of vilazodone on anxiety symptoms in patients with major depressive disorder. Int Clin Psychopharmacol. 2014;29(6):351-356.

46. Gommoll C, Durgam S, Mathews M, et al. A double-blind, randomized, placebo-controlled, fixed-dose phase III study of vilazodone in patients with generalized anxiety disorder. Depress Anxiety. 2015;32(6): 451-459.

47. Gommoll C, Forero G, Mathews M, et al. Vilazodone in patients with generalized anxiety disorder: a double-blind, randomized, placebocontrolled, flexible-dose study. Int Clin Psychopharmacol. 2015;30(6): 297-306.
48. Durgam S, Gommoll C, Forero G, et al. Efficacy and safety of vilazodone in patients with generalized anxiety disorder: a randomized, double-blind, placebo-controlled, flexible-dose trial. J Clin Psychiatry. 2016;77(12):1687-1694.

49. Robinson DS, Kajdasz DK, Gallipoli S, et al. A 1-year, open-label study assessing the safety and tolerability of vilazodone in patients with major depressive disorder. J Clin Psychopharmacol. 2011;31(5):643-646.

50. Ferguson JM. SSRI Antidepressant medications: adverse effects and tolerability. Prim Care Companion J Clin Psychiatry. 2001;3(1): 22-27.

51. Clayton AH, Kennedy SH, Edwards JB, et al. The effect of vilazodone on sexual function during the treatment of major depressive disorder. $J$ Sex Med. 2013;10(10):2465-2476.

52. Clayton AH, Durgam S, Li D, et al. Effects of vilazodone on sexual functioning in healthy adults: results from a randomized, double-blind, placebo-controlled, and active-controlled study. Int Clin Psychopharmacol. 2017;32(1):27-35.

53. 2015 Florida Best Practice Psychotherapeutic Medication Guidelines for Adults. The University of South Florida, Florida Medicaid Drug Therapy Management Program sponsored by the Florida Agency for Health Care Administration. Available from: www.medicaidmentalhealth.org. Accessed June 1, 2017.
Neuropsychiatric Disease and Treatment

\section{Publish your work in this journal}

Neuropsychiatric Disease and Treatment is an international, peerreviewed journal of clinical therapeutics and pharmacology focusing on concise rapid reporting of clinical or pre-clinical studies on a range of neuropsychiatric and neurological disorders. This journal is indexed on PubMed Central, the 'PsycINFO' database and CAS,

\section{Dovepress}

and is the official journal of The International Neuropsychiatric Association (INA). The manuscript management system is completely online and includes a very quick and fair peer-review system, which is all easy to use. Visit http://www.dovepress.com/testimonials.php to read real quotes from published authors. 